\title{
The Effect of Globalism to the Transformation of the Information Mediaculture
}

\author{
Kodirov Nodirbek Mamasolievich \\ Department of the Theory and Practice of Building a Democratic Society in Uzbekistan, Faculty of Social-ecanomical, Namangan State \\ University, Namangan State University, Namangan, Uzbekistan
}

Email address:

nodir_ziyo87@mail.ru,n.qodirov@umail.uz

\section{To cite this article:}

Kodirov Nodirbek Mamasolievich. The Effect of Globalism to the Transformation of the Information Mediaculture. International Journal of European Studies. Vol. 4, No. 1, 2020, pp. 9-12. doi: 10.11648/j.ijes.20200401.12

Received: December 20, 2019; Accepted: January 4, 2020; Published: May 28, 2020

\begin{abstract}
The article analyzes the globalization of social, economic, political, cultural and spiritual relations in the modern world, creating the necessary conditions and opportunities for changing the values, destinies of civilization in one way or another. Also, for the sake of globalization of information culture, both the ways and means of exploitation lie in the alternatives to the social benefits of the information culture of society based on the positive and negative aspects of each other. In this context, the effects of the globalization of information culture, the directions and functional significance of the impact on human civilization are: ethics - good and evil; aesthetics - beauty and ugliness; economics - profit and loss; political science - progress and regression; Complex analysis of the theological science in the context of such categories as sin and good, its essence and functional significance. The article analyzes the developmental laws, positive and negative consequences of the transformation and globalization of information culture in the context of meeting the universal and "mental needs" of the global information space and outlines theoretical and methodological foundations and practical directions for the development of objective conditions and subjective factors. The article was supposed to be the basis for the eradication of the ideological polar world and the emergence of a new format of international cooperation in all socio-political relations, theoretically, the negative effects of civilization related to the transformation and globalization of information culture. Whereas, the emerging global social and political experiences increase the risk of escalation of global problems that are the result of modern civilization, the process of transformation and globalization of information culture based on universal moral and ethical principles, democratic and humanistic principles: humanization of culture, especially the media system.
\end{abstract}

Keywords: Information Culture, Globalization of Information Culture, Humanization of Information Culture, Paradigm of Information Culture, Moral and Moral Values, Factors That Determine Information Culture, Effective Globalization, Anomalous Globalization

\section{Introduction}

In the time of globalization of social, economic, political, cultural, spiritual relations of today's world countries, it creates the necessary conditions and opportunities for changing the values, destinies of civilization in one way or another. "On the one hand, new information and technology systems are being formed around the world. On the other hand, there is a growing conflict of interest between the major powers and the competition in the global market." [1]

The globalization of modern civilizations, which predicts the historical development of humanity, has only been the subject of scientific research since the middle of the twentieth century, and has emerged as a special phenomenon, "Globalism," exploring this process as a social phenomenon. As a result of the differentiation of this discipline, theoretical and methodological foundations, categories and concepts of globalization of social phenomena have been formed, and the system of alternative scientific doctrines on the criteria for assessing its historical stages, directions and consequences is being defined.

\section{History of the Subject}

The phenomenon of globalization, according to various doctrines, is, on the one hand, the objective law of the 
development of human civilization, and it offers real opportunities. In particular, the tendencies of globalization of civilizations (regardless of their sphere and scope) are the determinants of international social, economic, political, cultural and other relations: integration, universalization, and internationalization. On the other hand, the transformation and globalization of its negative consequences are creating a whole new set of socio-political problems and reinforcing existing ones. In other words, the negative effects of the "information pressure" on society are: marginalization of the individual, alienation of historical values, escalation of nihilistic attitudes, escalation of "mass culture", egoism, cosmopolitanism, individualism, ethnocentrism, xenophobia and other negative phenomena.

However, the history of civilizations shows the relative importance of positive consequences in the overlapping directions of globalization. After all, in the antipodes of good and evil, creativity and destruction, good and evil, progress and regression and other, the priority of positive developments in the development of society was crucial. In particular, the advancement of the mind - from the sentiments, the common interests - to the individualindividual (especially utilitarian-mercantil) interests has provided the present stage of sustainable human development. Also, the tendency of modern global civilization to make this phenomenon conditional and relative to the geographical division of the West and the East.

In general, the positive results of the globalization process should be assessed in the context of the emergence of universal universal moral and cultural values, legal democratic principles and ethical norms, aggravation and globalization of conflicts between "civilizations", their "poverty", deficiency, imperfection in the culture of information exchange. That is, conflicting needs, interests and tendencies cause "civilizations clash" and conflict of values [3].

\section{Results and Discussion}

These conflicts are analyzed in the context of the information culture in the context of the historically established political and economic status of the various ethnic and confessional units in the culture of information, it also clarifies and transforms the vision of civilization trends, especially the stages of development of information culture. to understand the meaning, significance and functional significance.

Therefore, the process of globalization, in particular, the problems of globalization of "positive pressures" of globalization "information pressure", is the focus of the international community. After all, the intensification and globalization of information culture transformation is a prerequisite for sustainable development of nations and nations around the world. That is, the use of progressive science, intellectual potential, technical, innovative and technological advances in any historical period and society will lead to the development of a global and global information culture. However, the use of these methods to justify certain utilitarian-mercantile needs and interests is globalizing the threat of anti-humanistic, unethical "mass culture".

For the sake of globalization of information culture, both the ways and means of use are based on the positive and negative aspects of each other's social benefits to society's media interests. In this context, the effects of the globalization of information culture, the directions and functional significance of the impact on human civilization are: ethics - good and evil; aesthetics - beauty and ugliness; economics - profit and loss; political science - progress and regression; The analysis of theological science in the context of such categories as sin and goodness leads to a comprehensive systematic understanding of its essence and functional significance.

The process of transformation and globalization of information culture is based on universal moral and ethical norms, democratic and humanistic principles: the main purpose of organizing, managing and controlling the culture, and in particular the media culture. Theoretically, the principle of civilization to solve any global problem is the basis for the creation of a more universal methodology for finding and integrating the principles of the various alternative theories of culture into a common consensus.

In general, when we look at alternative approaches to the social phenomenon of globalization, which is controversial in philosophical literature, from the perspective of globalization of information culture, we see two opposing approaches to this process - radicalism and liberalism. Radicalism scholars dominate the pessimistic conclusion that globalization is the birth of a new type of world war [4], the formation of a "mass culture", the possibility of nationalization of the nation into spiritual poverty, crisis, and the disintegration of marginalized [5]. In the doctrines of the flow of liberalism, culture in general (as a co-occurring form of civilization), in particular, the process of transformation and globalization of modern information media - is the objective law of universal development and the possibility of securing its future.

The globalization of information culture, on the one hand, reflects the integration, internationalization, synthesis and universalization of national values based on the needs and interests of mankind. On the other hand, national information culture as a component of universal spiritual and cultural values, makes concrete the subject-subject relations in the transformation of all forms of culture.

On this basis, the globalization of information culture reflects the "technological" potential of transforming national values in a particular information space and is the main criterion that determines the stages of integration of cultural relations of humanity and the degree of globalization. At the same time, the transformation of information culture results in the horizontal and vertical directions should be considered as their basis and result.

In other words, the international community's cooperation in preventing and addressing global issues in general, including the escalation of the "mass culture" escalation, has 
an irrelevant axiomatic objective reality and a stable imperative postulate. After all, the solution of global problems requires concerted action of all countries, international and regional organizations and peoples in the information exchange policy. President Shavkat Mirziyoyev's Address to the Oliy Majlis of the Republic of Uzbekistan: "Worldwide conflict of interests, competition, and the international situation are aggravating. As we make action plans for the coming year, we need to clearly define the priorities of our development, taking into account this difficult situation in the international arena." [7]

However, it is well-known that there is still an individual interest in utilizing the utilitarian-mercantile "mental needs" of different nations, states, and regions to justify various ethnoegoistic, ethnoegocentocentric causes, and not to use the potential of their satisfaction. Therefore, it is important to determine the authenticity of the information, the representativeness of the sociological data in addressing the current global system of problems: local, national and regional needs, individual interests. At the same time, the question of using the potential of international global institutions for the organization, management and control of information culture (alternative approaches to addressing global problems), humanism and democracy in general remains open.

In his book "High spirituality is an invincible force," the first President of Uzbekistan, Islam Karimov, described in detail the positive and negative effects of the phenomenon of globalization on our country. Particularly, the strengthening of integration and cooperation between countries and peoples, the creation of favorable conditions for foreign investment, capital and goods, free movement of labor, the creation of many new jobs, the rapid spread of modern communications and information technologies, scientific achievements, various values. The generalization on a universal basis, the new quality of intercultural dialogue, and the increased capacity for mutual assistance in environmental disasters - Chase in progress" [11] due to globalization, he said.

President Shavkat Mirziyoev said, "In the great history, nothing is left without a trace. It is stored in the blood of nations, in its historical memory and manifested in its practical work. Therefore, it is powerful. Preservation, study and preservation of historical heritage is one of the most important priorities of state policy.

In the context of globalization of new threats, including the dangers of "mass culture" and the emergence of addictive moods, the danger of loss of morals and values, this is important, "summarized this conclusion in the context of globalization of information culture.

In turn, the effectiveness of these factors is reflected in the character of each nation: historically developed mental features, the ability to summarize and apply the international experience of the political system in building a democratic state and civil society. After all, it is necessary to ensure the harmonization of the international institutional system of organizing, controlling and controlling the globalization of information culture: the organizational conditions and subjective factors that determine the legal basis, moral and ethical norms, political political mechanisms, technical and technological basis, and overall process stability. requires.

In general, the impact of the transformation and globalization of media culture on media impacts on the effectiveness and implementation of the following directions:

Firstly, the nature and status of any national state, in the aforementioned area, of its international status and status, in the world community: its interest in social, economic, political and cultural cooperation;

Second, preserving the historical heritage of the historically formed national information culture, the maturity of transformative conditions and subjective factors that creatively develop the experiences of the peoples of the world;

Third, to understand the objective nature, necessity, possibilities of information culture globalization needs, to define the strategic tasks of forecasting trends and trends of development;

Fourth, the integration of universal and national information values, the establishment of international institutional systems, constructive methods, rational tools, innovative technologies for the development of global information culture;

Fifth, the information culture will depend on the democratization of the political mechanisms of the governance system, which will coordinate and harmonize the activities of national and regional entities that are globalizing.

\section{Conclusions}

In this context, the eradication of the ideological polar world and the formation of a new format of international cooperation in all socio-political relations should, in theory, be the basis for eliminating the negative effects of civilization associated with the transformation and globalization of information culture. However, the emerging experiences of the existing global social and political existence exacerbate the threat of escalation of global problems as a result of modern civilizations.

\section{References}

[1] Mirziyoev. SH. The work of the great nation is great, the life is bright and the future is bright. T., Uzbekistan. 3. T. p-320.

[2] O. K. Bezgranichny mir. -M:, 1991. -pp. 29-30.

[3] Aksyumov BV "Civilization" as Conflict Medium Tradition and Modernity. // "Identichnost and dialog cultur e epoxu globalization". The Material Mejdunarodnoy NauchnoPractical Conference. Bishkek, 2007. pp. 9-10.

[4] http://uz.infocom.uz/more.php?id=207_0_1_0_M.

[5] Otamurodov S. Globalization and the nation. Tashkent. New Generation, 2008. - p-201. 
[6] Yuldasheva F. Metodologic problems globalization process. // Social opinion. Human rights. 2008. No. 2. pp. 70-71.

[7] Sh. Mirziyoev. The work of the great nation is great, the life is bright and the future is prosperous. T., Uzbekistan. 3. T. P 5.

[8] Makhkamova D. Central Asians and Strangers Vostoka na puti sotrudnichestva and cult. // Social opinion. Human rights. 2004. No. 2. p. 20.

[9] Adilkhodjaeva SM Globalization and Business Development // Social Sciences in Uzbekistan. 2008 No. 3. p. 55.
[10] Kuznetsov V. Geoculture. Основы geoculturnoy speaker bezopasnosti v mire XXI vec: cult set. M., Kniga i Business, 2003. p. 416.

[11] Karimov I. High spirituality is an invincible force. 2008. pp111-112.

[12] Huntington S. Stolknovenie civilization. -p. 409. 